Anna Kurpiel

[Wrocław]

\title{
Sprawozdanie z międzynarodowej konferencji „Archiwa Społeczne. Modele współpracy z państwem" (Warszawa 6.10.2014 r.)
}

Wrocławski Rocznik

Historii Mówionej Rocznik IV, 2014

ISSN 2084-0578

6 października 2014 r. odbyła się w Warszawie, w Domu Spotkań z Historią, międzynarodowa konferencja „Archiwa Społeczne. Modele współpracy z państwem". Organizatorem konferencji była Fundacja Ośrodka KARTA we współpracy z Naczelną Dyrekcją Archiwów Państwowych, a patronat medialny nad wydarzeniem objął popularny portal Historia i Media.

Konferencja, będąca częścią większego programu Ośrodka KARTA „Stabilizacja archiwistyki społecznej w Polsce”, miała przede wszystkim na celu pokazanie różnych modeli współpracy państwa z niezależnymi inicjatywami archiwistycznymi na świecie. $Z$ tego względu zaproszono prelegentów z kilku krajów - goście z Niemiec, Wielkiej Brytanii i Włoch byli obecni w Warszawie, natomiast z Nową Zelandią i Australią łączyliśmy się przez Skype'a.

Konferencję rozpoczął Zbigniew Gluza, prezes Ośrodka KARTA, podkreślając przede wszystkim wyjątkowe miejsce konferencji - przy DSH działa największe archiwum historii mówionej w Polsce, a także 33-letnią historię KARTY. Gluza bardzo klarownie wyjaśnił koncepcję archiwistyki społecznej, która, w przeciwieństwie do zbiorów archiwalnych, nie powinna znajdować się w rękach państwowych lub prywatnych, a właśnie w społecznych. 
318 Obecność AS-ów, które, według Zbigniewa Gluzy powinny mieć stałe miejsce w strukturach Archiwów Państwowych, świadczy zaś o poziomie zaawansowania rozwoju społeczeństwa obywatelskiego.

Archaicznymi zasadami, a w szczególności skostniałym podziałem zasobów na państwowe i niepaństwowe, tłumaczył Naczelny Dyrektor Archiwów Państwowych, Władysław Stępniak, brak możliwości wsparcia AS przez AP. W swoim referacie „Archiwa państwowe wobec wytwórców niepaństwowego zasobu archiwalnego" przedstawił jednak kilka projektów AP aktywizujących Polaków do odszukiwania i - ewentualnie - przekazywania - rodzinnych lub lokalnych pamiątek.

Katarzyna Ziętal z Ośrodka KARTA zarysowała sytuację AS-ów w Polsce, które gromadzą materiał bardzo różnorodny (jednak w $80 \%$ są to fotografie), oraz przedstawiła projekt „Stabilizacja archiwistyki społecznej w Polsce”, którego celem jest profesjonalizacja archiwów społecznych, o których, według badań przeprowadzonych w 2013 r., słyszało 12\% Polaków.

O tym, że termin AS jest nadal bardzo mało znany w Polsce, mimo że samo gromadzenie pamiątek rodzinnych i regionalnych przez lokalnych „strażników tradycji” oraz lokalnych pasjonatów historii jest zjawiskiem często spotykanym $\mathrm{w}$ małych miasteczkach i wsiach, mówiła również Anna Kurpiel z Centrum Willy'ego Brandta UWr. w drugiej części konferencji. W swoim wystąpieniu przedstawiła zagadnienie archiwistyki społecznej, wpisując je w szerszy nurt historii publicznej w Polsce, jak również na dwóch przykładach z własnych badań terenowych, pokazała niezwykle pozytywny wpływ „oddolnych archiwistów” na poczucie wspólnoty i tożsamości małych społeczności lokalnych.

Pozostali uczestnicy konferencji, pochodzący z różnych krajów europejskich i pozaeuropejskich, w referatach przedstawili działalność AS w swoich własnych krajach, poruszając także problem ich współpracy z państwem. I tak, dyrektor Agencji Nadzoru Archiwów Regionu Emilia Romagna w Bolonii, Stefano Vitali, opowiedział o włoskich inicjatywach wpisujących się w nurt archiwistyki społecznej (sam termin AS nie jest we Włoszech rozpoznawalny), a więc przede wszystkim archiwach prywatnych kolekcjonerów, fundacji oraz partii politycznych, nad którymi kontrolę sprawują utworzone w 1939 r. w każdym z włoskich regionów Agencje Nadzoru Archiwów.

Joanna Newman, konsultantka do spraw dokumentacji i archiwów, przedstawiła przekrojowy opis stanu i problemów archiwistyki społecznej w Nowej Zelandii. Jednym z przedstawionych przez nią postulatów była 
konieczność wsparcia oddolnego ruchu przez państwo, jednak, z powodów finansowych, jest ono nadal zbyt małe. Dlatego, według Joanny Newman, nadal kluczową rolę w tworzeniu AS odgrywają zaangażowani działacze, pracujący na zasadzie wolontariatu.

Z problemami finansowymi borykają się także archiwa społeczne w Kanadzie, szczególnie obecnie, gdy - według doktorantki na Wydziale Historii University of Toronto, Gabrieli Pawlus-Kasprzak - humanistyka jest coraz mniej dotowana przez państwo. W swoim wystąpieniu skoncentrowała się na pokazaniu potencjału archiwów społecznych tworzonych przez mniejszości narodowe i etniczne mieszkające w stanie Ontario.

O różnorodności archiwów społecznych, których liczbę w Wielkiej Brytanii szacuje się na 2-5 tys., opowiedziała Julianne Nyhan, adiunkt na Wydziale Informacji University Collage London. W swoim bardzo ciekawym referacie podkreśliła aktywną rolę wspólnoty w tworzeniu i zarządzaniu archiwum społecznym, także odnośnie do formy jej współpracy z państwem.

Ostatni głos należał do Cornelii Wezel - kierowniczki archiwum w Fundacji Niemieckiego Ruchu Kobiecego, która opowiedziała o archiwach niemieckich ruchów społecznych, takich jak: ruchu ekologicznego, feministycznego, wsparcia dla krajów Trzeciego Świata oraz ruchu gejowskiego i lesbijskiego. Tak jak w przypadku innych krajów, również w Niemczech podstawowym problemem dla większości archiwów społecznych jest brak należytego finansowania. 60\% niemieckich „archiwistów społecznych” działa za darmo, reszta według zasady „wynagrodzenie za pół etatu, praca na cały etat”. Jednak niemieckie AS nadrabiają improwizacją i kreatywnością, a także rozwiniętą współpracą, jak np. archiwa feministyczne, które spotykają się co roku w celu wymiany doświadczeń. Co ciekawe, w Niemczech nie ma żadnej dyskusji między Archiwum Państwowym a AS-ami, także z tego względu, że każdy z Landów prowadzi własną politykę archiwalną.

Po wystąpieniach nastąpiła burzliwa dyskusja zapoczątkowana przez Zbigniewa Gluzę pesymistyczną diagnozą: „jeśli przyjąć to, co tu się zdarzyło za punkt wyjścia, to nie mamy gdzie iść". Stwierdził on, że z wystąpień konferencyjnych wyłania się chaos organizacyjny, brak jasnej drogi oraz jednej spójnej definicji AS. Jednak pozostali uczestnicy konferencji skontrowali ten pesymizm, szczególnie goście zagraniczni, według których sytuacja archiwistyki społecznej w Polsce przedstawia się bardzo dobrze. Julianne Nyhan zauważyła, że najważniejsze jest rozpoznanie autonomii archiwów społecznych i skupienie się na ich lokalnej specyfice. Natomiast Cornelia Wezel dodała, że w jej opinii jedna wspólna definicja AS jest niepotrzebna, a problem 